\title{
The Establishment of Ministers of Handling Affairs in Xining
}

\author{
Yangmei Ding \\ College of History and Culture \\ Northwest Normal University \\ Lanzhou, China 730070
}

\begin{abstract}
In the first year of the Yongzheng reign, the government of Qing Dynasty put down the rebellion of the Lob Tsangdanjin and implemented the rehabilitation works proposed by Nian Gengyao. These rehabilitative measures strengthened the Qing government's rule over Qinghai, cleared the obstacles for the Qing government to directly administer Qinghai and created the conditions for setting up the government agency that directly administered the affairs in Qinghai, Mongolia and Tibet. In the third year of Yongzheng reign (1725), it formally set up "imperial envoy who handled Qinghai and Mongolia affairs" in Xining. And this imperial envoy could manage Qinghai, Mongolian and Tibetan affairs. The Qing government set up ministers of handling affairs in Xining under the court of Colonial Affairs. And then, it began the overall governance of Qing government.
\end{abstract}

Keywords - the rebellion of Lob Tsangdanjin; ministers of handling affairs in Xining; court of Colonial Affairs; specialized in managing affairs in Mongolia

\section{INTRODUCTION}

In the fifty fifth year of Kangxi reign (1716), the Qing government sent troops to Tibet to conquer the Zungar tribe. The Qing government set up the Gelun system in Tibet to jointly administer the administrative affairs in Tibet. The Qing government set up local government that directly controlled Tibet. With its great strength, the Qing government successfully replaced Mongol Khan of the Khoshut who ruled Tibet. The Qing government began the direct rule over Tibet, and the governance of Khoshut leader had come to an end. After the settlement, the Qing government had no longer recognized the inheritance of the Khoshut descent. Then, Tibetan nobility Kancennas took over the management of the Tibet. The measures taken by the Qing government completely eroded the desire of "being Tibetan king" of Lob Tsangdanjin. And then, it broke out the rebellion of Lob Tsangdanjin. After the settlement of the rebellion, the Qing government adopted "The thirteen rehabilitation articles of Qinghai" and "Twelve affairs of limitation in Qinghai" proposed by Nian Gengyao. These rehabilitative measures strengthened the Qing government's rule over Qinghai, cleared the obstacles for the Qing government to directly administer Qinghai and created the conditions for setting up the government agency that directly administered the affairs in Qinghai, Mongolia and Tibet.
The Qing government settled down the rebellion of Lob Tsangdanjin. According to the actual conditions in Qinghai, the Qing government adopted Nian Gengyao's rehabilitative measures, conducted a large-scale rectification of the political, economic and religious aspects in Qinghai, and strengthened the jurisdiction over Qinghai. However, these measures were only implemented to clean up the slack of the war and pave the way for the Qing Dynasty to directly govern Qinghai.

II. THE GOVERNANCE IN QINGHAI, MONGOLIA AND TIBET IN EMPEROR KANGXI PERIOD AND THE EARLY PERIOD OF YONGZHENG REIGN

During the Kangxi reign, the Qing government set up the minister to handle minority affairs. However, according to actual situations, these ministers would convey these facts to the Qing government. And these ministers didn't specialize in handling the affairs of Mongolia. The princes would meet each other to discuss the situation in their unions. And Lob Tsangdanjin was the leader. He could govern Qinghai independently. And then, he became more and more cruel. If someone had violated Lob Tsangdanjin, he would send troops to conquer that tribe. In the Mongolia, all the tribes had to suffer his atrocity. And he established the prestige [1].

Since the first year of the Yongzheng reign, the Qing government would send the members of the Court of Colonial Affairs to handle the affairs in Qinghai [2]. By the time of the first year of Yongzheng reign, "the Qing government appointed Chang Shou as an additional assistant minister of the Court of Colonial Affairs to handle the affairs in Xining" [3]. And the Court of Colonial Affairs would manage national affairs. The assistant minister of the Court of Colonial Affairs Chang Shou would take charge of Qinghai's affairs in Xining. Lob Tsangdanjin, Pesukwan Zar and other people sent four thousand soldiers to rob Erdene Okktorkoto and other Heshuote nobility. Yongzheng Emperor appointed assistant minister of the Court of Colonial Affairs Chang Shou that we should sent ministers to persuade them to be good with each other. If Lob Tsangdanjin invaded the border of the Qing, we must punish him. And with the reconciliation of the princes, the Qing government would solve this event. Also, the Qing government would send the ministers and Lama to persuade them to be good with each other. You should plan and 
prepare this event. And you could communicate this event with Nian Gengyao. [4] The emperor also ordered the assistant minister of Qinghai Chang Shou to perform the memorial. When Chang Shou reached Shalatu governed by Lob Tsangdanjin, he should declare imperial edict and persuade these minority to get along with each other in harmony. Chang Shou would make a report of the situation to the Qing government. According to the situations of Mongolia, Lob Tsangdanjin ordered the other nationalities to call him Dalai Lama Taiji. And the other Taiji couldn't use the old names. All of them couldn't use the princes and other titles conferred upon by the emperor. We can try to figure out his intentions carefully. Firstly, Lob Tsangdanjin wanted to destroy Erdene Okeketone, and then Khan Danjin. And then, he would monopolize Qinghai with all Taiji. He proposed a decree to be Ili Khan. He would remotely control Qinghai in his fief. Obviously, we can see his intentions. Also, the Zungar soldiers had come to Gesi. In the month, they would come to Qinghai and so on. [5] Chang Shou described the situation in his memorial to the throne. In August and September of the first year of the Yongzheng reign, Lob Tsangdanjin organized the allegiance and made the rebellion. He had planned for a long time. The assistant minister of the court of colonial affairs in Xining described the situations of Lob Tsangdanjin [6]. Emperor Yongzheng sent soldiers to conquer Lob Tsangdanjin. And Emperor Yongzheng ordered that they should plan all the events with Sudan, Yue Zhongqi and Changshou. They jointly developed the strategies. And they had better not miss the opportunities to defeat Lob Tsangdanjin. Although we have the strong soldiers, we had better not look down on the betrayers. If Lob Tsangdanjin resisted, we should destroy all of them. You can dispatch soldiers to destroy Lob Tsangdanjin, clear and secure the border. [7] And then, people can see that the emperor may recover the duties of Chang Shou according to the actual situations. The emperor wanted him to handle the emergency. However, his duties were to convey the situations, not specialize in handling the affairs in Mongolia. [8]. And Chang Shou had no rights to deal with the actual affairs. Later, Chang Shou was punished for dereliction of duty. The dereliction mainly included several concepts: First, he did not convey the actual situations timely, and he didn't describe the details on the rebellion of Lob Tsangdanjin. Second, he didn't carry out his duties of the position. And he had been caught by Lob Tsangdanjin. Then, Lob Tsangdanjin released him. "The imperial archive of Qing Dynasty" records that the assistant minister of the court of colonial affairs Chang Shou should handle the affairs in Qinghai. However, he didn't describe the rebellion of Lob Tsangdanjin in his memorial to the throne. And Chang Shou took all of the affairs to Nian Gengyao. He left Xining. In Qinghai, he was caught by Lob Tsangdanjin. And then, he was released by Lob Tsangdanjin. He was absent of his duties. Chang Shou was put in the prisons in Xi'an. Dorje was captured by the betrayers. However, he didn't yield to the betrayers. Then, the emperor praised his sacrifice. According to martyrdom, the department made funeral for him [9].

Since the second year of Yongzheng reign, the emperor sent the assistant ministers to help the ministers to handle the affairs in the manor." [10] In the third year of Yongzheng reign, the Court of Colonial Affairs ordered assistant minister E Laigong and Vice-general Da Nai to Qinghai to reward poor. They were divided into sections. It found that there were 29 sections in Qinghai and Mongolia. And that was 29 banners. Each banner was provided with an assistant Taiji, janggin, vice-janggin and colonel of the guards. According to the size of the account, it should take 150 households as a collar. And there were a total of 114 and half collars. Each collar was provided with one banner and a military officer. Jasagh, King, the princes and Taiji of each banner could inherit the titles of nobility. And the emperor should issue the title. The assistant Taiji could be introduced. With the permission of Vice-general Da Nai, the almanac and official's salary of each Jasagh were issued by Qing government. And Xining official affair issued official's salary. The Jasagh could be divided into four classes. They would pilgrimage the emperor each year, go round and round. It also ordered that the minister should gather all the Jasagh once a year. And these Jasagh couldn't gather privately. In this year, the vice-general Da Nai would be issued the title of the secretary. The Qing government would give him one thousand and five hundred silver. And then, he would handle all kinds of affairs in Qinghai [11]. Da Nai and E Lai were ordered to implement the rehabilitation measures put forward by Nian Gengyao. Qinghai and Heshuote Mongolia would follow the example of Inner Mongolia to implement Jasagh system. The comprehensive governance of Qing government in Qinghai should be attributed to the establishment of ministers of handling affairs in Xining.

\section{TO SET UP MINISTERS OF HANDLING AFFAIRS IN XINING TO GOVERN QINGHAI, MONGOLIA AND TIBET IN THE THIRD YEAR OF YONGZHENG REIGN}

In December of the third year of Yongzheng reign (1725), the emperor ordered Vice-general Da Nai to govern all the affairs in Qinghai [12]. Da Nai became the first officer to specialize in handling the affairs in Qinghai [13]. It formally established government office for imperial envoy in Xining to handle the affairs in Qinghai and Mongolia. And the minister governed the pastoral area of Riyueshan Mountain. The Qing government set up post to go through Tibet. These posts were led by the court of Colonial Affairs of the Central Government [14]." Since then, the commissioner specially handled the Mongolian and Tibetan affairs in Qinghai area. There were rules for the governance of Mongolian affairs. [15] During the Yongzheng Reign, it firstly established the "minister system" to manage the affairs of Mongolian and Tibetan minorities. And there were essential differences from the ministers who had previously been sent to Qinghai to handle affairs.

In the early period of the Qing Dynasty, in order to strengthen the rule of ethnic minorities, the Qing government set up the court of Colonial Affairs in the central government to govern ethnic affairs of frontier areas. In the third year of Yongzheng reign (1725), a minister of handling affairs was set up in Qinghai. The minister of handling affairs in Xining was an institution directly under the administration of the Court of Colonial Affairs, which represented the Central 
Government and the court of Colonial Affairs to administer the areas of Mongolia and Tibet.

During the Yongzheng period, it especially established ministers of handling affairs in Xining. And this institution was under the court of Colonial Affairs. It could govern the affairs of Mongolian and Tibetan minorities on behalf of the Central Government and the court of Colonial Affairs at that time. And it tried to find a way of governing the local multigroups and pluralistic society in the management system [16]. The governance of ministers of handling affairs in Xining became a permanent system of Qing dynasty.

\section{THE EFFICIENCY OF MINISTERS OF HANDLING AFFAIRS IN XINING}

With the achievements of the governance of ministers of handling affairs in Xining through Kangxi reign, Yongzheng reign and Qianlong reign, it is not hard to imagine the success of the minister system [17]. Therefore, it firstly established the minister system in the area of Mongolia and Tibet. Later, the minister system was established in Tibet and Xinjiang. It had a positive impact on ethnic governance in the border areas at that time. Moreover, it had impact on setting up a province in Qinghai. It also had a significant impact on the social development in Qinghai. It had important implications for the governance of contemporary ethnic areas.

First, we should adhere to the principle of administering according to law, establish and improve the legal system in ethnic areas. We can see the remarkable feature of the Qing government's administration over the areas of Mongolia and Tibet in Qinghai. The Qing government paid more attention to the establishment and improvement of laws and regulations and systems, and administration according to law. [18] After the Lob Tsangdanjin event, "13 articles of rehabilitation works of Qinghai" and "12 articles on the limition of Qinghai" were formulated and promulgated. Since then, the minister of commerce proposed that all the minorities should obey the law of the Qin Dynasty. The minister should translate the law into the Mongolian words. The ministers required all the princes, Taiji and Jasagh to follow this law. [19] Thus, the "Mongolian law" was implemented in Mongolian tribe of Qinghai. In the 12th year of the Yongzheng reign (1734), the Yamen for ministers of handling affairs in Xining selected 68 articles from the Mongolian law precedent. And these articles were compiled into "The governance of minorities in Xining". And this law was issued in the Yushu area. In addition, "Eight articles on various affairs in Qinghai and Mongolian areas", "Six articles on the affairs in Qinghai and Mongolian areas", "Eight articles on the rehabilitation works" reflected the management measures in Mongolian and Tibetan areas. Especially, it paid attention to the management of Tibetans. With the promulgation of laws in Mongolia and Tibet autonomous region of Qinghai, the governance of Qing government had been into a more mature and complete stage. The Qing government took outstanding results in the governance of Qinghai area. There are many for it. The most brilliant feature of the Qing government is to manage all the local areas with laws.
Second, we should safeguard national sovereignty and regional stability. We wouldn't ignore any form of ethnic separatist activities. In the first year of the Yongzheng reign, Lob Tsangdanjin event could be quelled promptly and quickly. It could prove that the Qing government had safeguarded the sovereignty of the country and the social stability of Gansu, Qinghai and Tibetan areas. [20]

Third, it should make the governance with local characteristics. And the government should respect the religious beliefs in the ethnic areas, attach importance to the influence of religion, and play an active role in religious monks. It also should strengthen the management and restraint of monasteries and monks. The Qing Dynasty not only adopted the strategy of supporting and utilizing Tibetan Buddhism to govern Mongolian and Tibetan Affairs in Qinghai, but also imposed severe penalties on monasteries and monks who endanger themselves and participated in the rebellion. The Qing government should play religious influence and active role of the religion, better use and control it to serve for the governance.

Fourth, the Qing government should pay attention to the social needs of the people of all ethnic groups in Mongolia and Tibet of Qinghai Province, improve the strategy of governance and the management system in time, safeguard and promote the social harmony and stability in the region. During the governance of ministers of handling affairs in the Mongolian and Tibetan areas of Qinghai, the Xining Office Minister took the ethnic policy of "governing according to the common custom". In order to meet the needs of governance in this region, we must constantly explore, conscientiously sum up experiences and change the ways and means of governing. And then, we should continuously improve and perfect the governance strategies to ensure the social stability of the Mongolian and Tibetan areas in Qinghai since the Emperor Yongzheng reign.

\section{CONCLUSION}

The Qing government would adopt the "vertical system" of ministers of handling affairs in Xining — the court of colonial affairs - the Emperor. Through the border management system of the court of colonial affairs, the Qing government could manage Qinghai, Mongolian and Tibetan areas. The ministers of handling affairs in Xining represented the court of colonial affairs and the Central Government to exercise their powers. The relationship between the court and the Qinghai area was changed directly. During Yongzheng reign, the emperor would appoint the ministers. The implementation of "vertical system" had achieved direct governance of Mongolian and Tibetan areas of Qinghai. It had become the memorial in the governance of border areas of Qinghai since Han dynasty."

\section{REFERENCES}

[1] Su Na. "The Archives of Yamen in Qinghai". "Qinghai affairs", written by Changbai Wenfu, Wei Mingzhang annotation, Qinghai People's Publishing House, 1993, p. 39.

[2] [Qing] Yang Yingju. "New Records of Xining House" vol. 20th Weapons, Qinghai People's Publishing House, 1988, p. 601. 
[3] "History of the Qing Dynasty" Vol. 8th, the eighth of sketches of emperors, 3rd of patriarchs.

[4] "The imperial archive of Qing Dynasty" Vol. 9th, the autumn of the first year of Yongzheng reign.

[5] "The imperial archive of Qing Dynasty" Vol. 10th and Vol. 11th. August and September of the first year of Yongzheng reign.

[6] "The imperial archive of Qing Dynasty" Vol. 10th. August of the first year of Yongzheng reign.

[7] "The imperial archive of Qing Dynasty" Vol. 12th. October of the first year of Yongzheng reign.

[8] "The imperial archive of Qing Dynasty" Vol. 15th. January of the second year of Yongzheng reign. "The history of Mongolia in Qinghai", edited by He Ling, Zhang Zhaoyun, Qinghai People's Publishing House, 2005, p.265.

[9] "Qing Shizong recorded" Vol. 15th. January of the second year of Yongzheng reign. "The history of Mongolia in Qinghai", edited by He Ling, Zhang Zhaoyun, Qinghai People's Publishing House, 2005, p.265.

[10] [Qing] Yang Yingju. "New Records of Xining House" vol. 20th Weapons, Qinghai People's Publishing House, 1988, p. 601.

[11] [Qing] Yang Yingju. "New Records of Xining House" vol. 20th Weapons, Qinghai People's Publishing House, 1988, p. 531.

[12] "Qing Shizong recorded" Vol. 39th. December of the third year of Yongzheng reign.

[13] [Qing] Yang Yingju. "New Records of Xining House" vol. 20th Weapons, Qinghai People's Publishing House, 1988, p. 601.

[14] [Qing] Yang Yingju. "New Records of Xining House" - Preface, Qinghai People's Publishing House, 1988, p. 14.

[15] Su Na. "The Archives of Yamen in Qinghai". "Qinghai affairs", written by Changbai Wenfu, Wei Mingzhang annotation, Qinghai People's Publishing House, 1993, p. 41.

[16] Jianing. "Formation of management system in multi-ethnic region of Qinghai and ministers of handling affairs in Xining in the Yong and Qian Dynasties, Qing History Research, August 2012 No.3.

[17] [Qing] Yang Yingju. "New Records of Xining House" — Preface, Qinghai People's Publishing House, 1988, p. 23.

[18] Chen Baiping. "Study on the policy in Gansu, Qinghai and Tibetan areas in the early Qing Dynasty", Journal of Northwest University for Nationalities, 2014, No.3.

[19] Zhecang Cairang. Qinghai and Mongolian Archives, Qinghai People's Publishing House, 1994, p. 4.

[20] Chen Baiping. "Study on the policy in Gansu, Qinghai and Tibetan areas in the early Qing Dynasty", Journal of Northwest University for Nationalities, 2014, No.3. 